G. STANKEVYCH, Dr. tech. Sciences, Professor, H. HONCHARUK, PhD. tech. Sciences, associate Professor,

I. SHIPKO, PhD. tech Sciences, associate Professor,

A. LIPIN, PhD. tech Sciences, associate Professor Odessa National Academy of Food Technologies, Odessa, Ukraine

\title{
REMOVAL OF MINERAL IMPURITIES FROM AFTER - HARVESTING RESIDUES OF CORN
}

\begin{abstract}
Abstrakt
Due to the energy crisis, special attention is paid to the production and use of biofuels. After-harvesting residues of corn (AHRC) may become a perspective source of energy for grain dryers. The following components of the AHRC are distinguished: stem, leaves, rod and wrapper of the cob. The AHRC is about $55 . . .60 \%$ of the total weight of the plant. The annual harvest of corn grain is more than 20 million tons. The calorific value at burning of wheat straw is $14.4 \mathrm{MJ} / \mathrm{kg}$, AHRC - $15.7 \mathrm{MJ} / \mathrm{kg}$. For comparison, the calorific value of wood on average is $14.24 \mathrm{MJ} / \mathrm{kg}$, and natural gas is $33.5 \mathrm{MJ} / \mathrm{m} 3$ [1]. Using the AHRC can significantly reduce the need for imported gas.

One of the directions of the use of plant raw materials as fuel is the production of granules [2]. The technology involves purifying raw materials from impurities, crushing and granulation. For a similar scheme, granulated feeds are produced. When picking up a harvester, following transportation and reloading, various contaminants, including mineral impurities in the form of stones, fall into the green mass. Having hit the crusher stones lead to damage to parts of the crushing mechanism, an accident and even an explosion. Clearing straw from impurities in agriculture is carried out on pneumatic separating machines [3]. But in the technical literature there is no data available to the separation of mineral impurities from the AHRC.

As a result of the experiments, it was found that leaves and stalks can be separated by air from large stones, and the separation of rods from stones is complicated. Under the influence of air flow, the rods are rotated along the pneumatic separating canal and unfolded by a long axis in parallel with the air flow, which leads to a decrease in the area of the midel section and to the reduction of the aerodynamic resistance. Therefore, to provide the required force acting on the core from the air stream, they increase the air velocity, which causes the capture and joint movement of the stones. To improve the separation process of the AHRC from the stones, it is necessary to develop a nutritional mechanism of the separator, in which to predict the possibility of orientation of the rods in the pneumocaps to the long axis across the air flow. This will enable you to reduce the air velocity required for separation and increase the difference in aerodynamic forces acting on the stones and rods. Accordingly, at the same time, the energy intensity of the pneumatic separation process will decrease and the efficiency of separating the AHRC from the stones increases. The separation of small stones smaller than $3 \mathrm{~mm}$ only by air is impossible, since they are picked up by the air flow that moves at the speed necessary for separating the stems $(7.5 \ldots 12.5 \mathrm{~m} / \mathrm{s})$. For the separation of small stones, it is proposed to use grid separators with combined air purge. For the complete separation of mineral impurities from corn cores, it is recommended to use hydro-separators.

Key words: after harvesting residues of corn, biofuels, pneumatic separating, separated machines, plant raw materials as fuel, clearing straw from mineral impurities.
\end{abstract}

\section{Introduction}

Because of energy crisis, special attention is paid to the production and to use of biofuels. After harvesting residues of corn (AHRC) may become a perspective source of energy for grain dryers. The following components of the AHRC are distinguished: stem, leaves, rod and wrapper of the cob. The AHRC is about $55 \ldots 60 \%$ of the total weight of the plant. The annual harvest of corn grain is more than 20 million tons. The calorific value at burning of wheat straw is $14.4 \mathrm{MJ} / \mathrm{kg}$, AHRC - $15.7 \mathrm{MJ} / \mathrm{kg}$. For comparison, the calorific value of wood on average is 14.24 $\mathrm{MJ} / \mathrm{kg}$, and natural gas is $33.5 \mathrm{MJ} / \mathrm{m}^{3}$ [1]. Using the AHRC can significantly reduce the need for imported gas.

One of the directions of the use of plant raw materials as fuel is the production of granules [2]. The technology involves purifying raw materials from impurities, crushing and granulation. For a similar scheme, granulated feeds are produced. When picking up a harvester, following transportation and reloading, various contaminants, including mineral impurities in the form of stones, fall into the green mass. Having hit the crusher stones lead to damage to parts of the crushing mechanism, an accident and even an explosion. Clearing

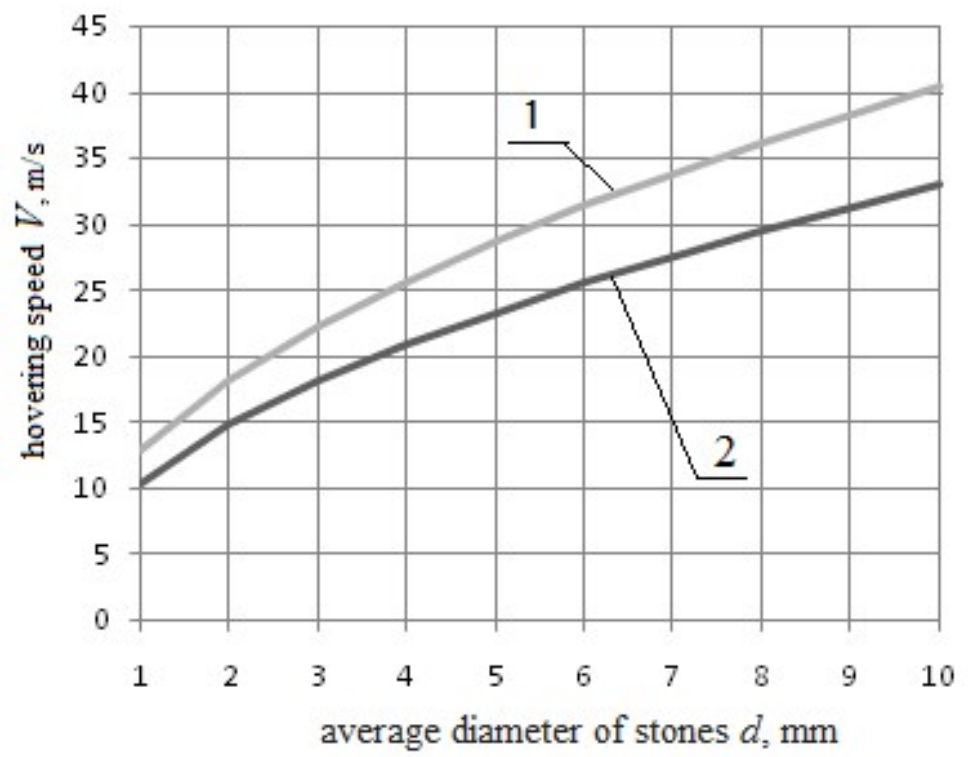

Figure 1 - Dependence of the hovering speed of stones on their average diameter $d$ and density $p_{K}$ :

(1) $-p_{K}=3000 \mathrm{~kg} / \mathrm{m}^{3}$; (2) $-p_{K}=2000 \mathrm{~kg} / \mathrm{m}^{3}$ 
straw from impurities in agriculture is carried out on pneumatic separating machines [3]. But in the technical literature there is no data available to the separation of mineral impurities from the AHRC.

\section{Aim of the research}

The purpose of the study is to determine the possibility of separating mineral impurities from the AHRC using pneumatic separation. Determine rational modes of pneumatic separation. Offer additional ways to clean AHRC from mineral impurities.

\section{Research results}

At the Department of Technological Equipment of Grain Production, ONAFT in the laboratory of ventilation and

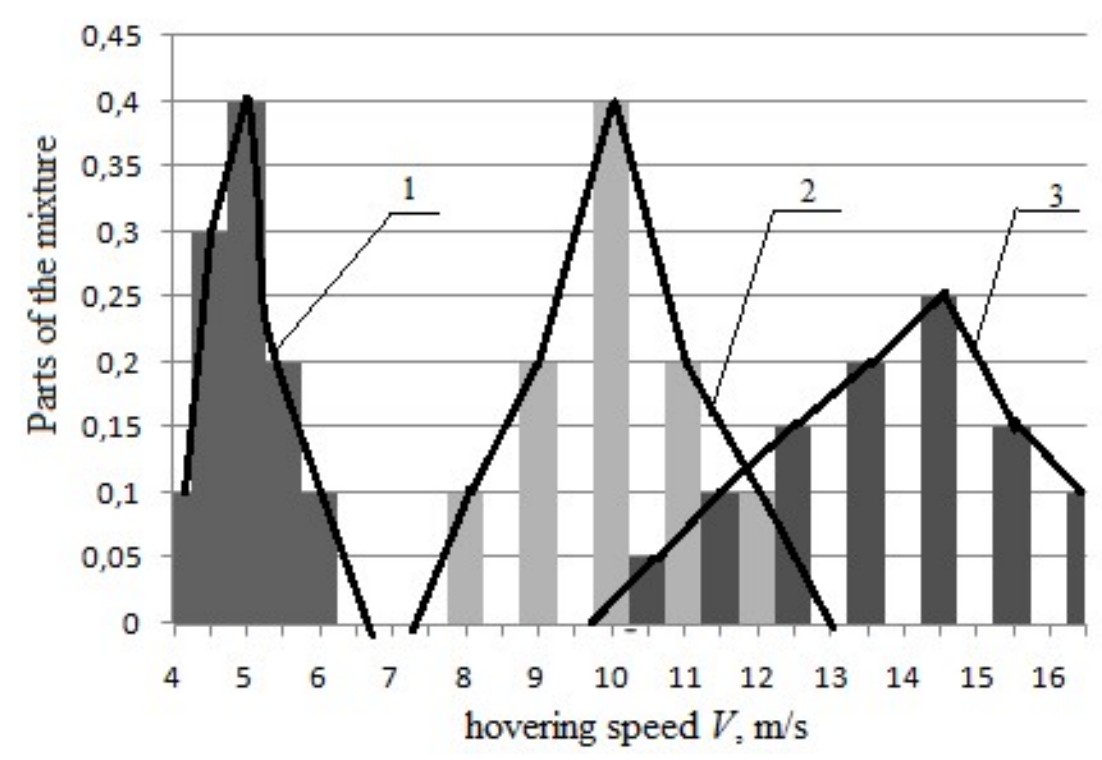

Figure 2 - Polygons of separation hovering speeds leaves (1), stems(2) and cobs(3)

pneumatic transport conducted experiments to determine the possibility of separating

mineral impurities from the AHRC. To determine the aerodynamic characteristics of the raw material was blown air in a laboratory analyzer-classifier. The dimensions of the samples presented on average were about $100 \ldots 150 \mathrm{~mm}$ in length. Also samples of mineral impurities in the form of stones in the size from $1 \mathrm{~mm}$ to $5 \mathrm{~mm}$ were presented. The density of stones was $2000 \ldots 3000 \mathrm{~kg} / \mathrm{m} 3$. The ability to separate the mixture is determined by the hovering speed of the particles.

The dependence of the hovering speed of stones on the average diameter and density was determined analytically by the formula [4] for spherical particles:

$$
V=\sqrt{\frac{4 p_{k} g d}{3 p \mu}}
$$

where $p_{K}$ is the density of stones,

$g$ - is the acceleration of free fall,

d? - is the average diameter of stones,

$p$ - is the density of air, $\mu$ is the coefficient of aerodynamic resistance of stones to airflow.

In the calculations, the following values were assumed: $g=9.81 \mathrm{~m} / \mathrm{s}, \mathrm{p}=1.2 \mathrm{~kg} / \mathrm{m}^{3}, \mu=0.2$.

The average diameter of stones was determined by the formula:

$$
d=\sqrt[3]{\mathrm{a}=\mathrm{B} \cdot \mathrm{c}}
$$

where $a, b$, c are respectively the length, width and thickness of the stone.

The values of the hovering speed for different anatomical particles of the AHRC are different. Experimental studies on determining the hovering speed of various parts of the AHRC showed that the lowest air flow rate was required for leaves $(4.0 \ldots 6.5 \mathrm{~m} / \mathrm{s})$, larger for stems $(7.5 \ldots 12.5 \mathrm{~m} / \mathrm{s})$. The hovering speed of the rods

is in the range of $10 \ldots 17 \mathrm{~m} / \mathrm{s}$. The moisture content of the samples was $11 \%$. Density of the rods was $600 \mathrm{~kg} / \mathrm{m}^{3}$. At a speed of $17 \mathrm{~m} / \mathrm{s}$ stones with a diameter of up to $3 \mathrm{~mm}$ and the rods rise up together.

\section{Conclusions}

As a result of the experiments, it was found that leaves and stalks can be separated by air from large stones, and the separation of rods from stones is complicated. Under the influence of air flow, the rods are rotated along the pneumatic separating canal and unfolded by a long axis in parallel with the air flow, which leads to a decrease in the area of the midel section and to the reduction of the aerodynamic resistance. Therefore, to provide the required force acting on the core from the air stream, they increase the air velocity, which causes the capture and joint movement of the stones. To improve the separation process of the control panel from the stones, it is necessary to develop a feed mechanism of the separator, in which to predict the possibility of orientation of the rods in the pneumatic channel to the long axis across the air flow. This will enable you to reduce the air velocity required for separation and increase the difference in aerodynamic forces acting on the stones and rods. Accordingly, at the same time, the energy intensity of the pneumatic separation process will decrease and the efficiency of separating the AHRC from the stones increases. The separation of small stones smaller than $3 \mathrm{~mm}$ only by air is impossible, since they are picked up by the air flow that moves at the speed necessary for separating the stems $(7.5 \ldots 12.5 \mathrm{~m} / \mathrm{s})$. For the separation of small stones, it is proposed to use grid separators with combined air purge. For the complete separation of mineral impurities from corn rods, it is recommended to use hydroseparators.

\section{REFERENCES}

1. Corn heat: how you can earn extra per hectare [Electronic resource]. - Access mode: // http. agravery.com/uk/posts/show/kukurudzane-teplo-ak-mozna-dodatkovo-zarobiti-na-gektari

2. Possibilities of procurement of corn for grain for energy use in Ukraine [Electronic resource]. - Access mode: // http://uabio.org/img/files/docs/position-paper-uabio-16-ua.pdf 
3. Nelyubov AI, Vetrov E.F. Pneumosuperating systems of agricultural machines. - Moscow: Mechanical Engineering, 1977. - $192 p$.

4. Technological equipment of enterprises for storage and processing of grain / A.Ya. Sokolov, V.F. Zhuravlev, V.N. Dushin et al .; Ed. AND I. Sokolova. - 5th ed., Revised. and add. - M .: Kolos, 1984. - 445 p.

Г.М. СТАНКЕВИЧ, д-р техн. наук, професор

Г.А. ГОНЧАРУК, канд. техн. наук, доцент

І.М. ШИПКО, канд. техн. наук, доцент

А.П. ЛІПІН, канд. техн. наук, доцент

\title{
ВІДДІЛЕННЯ МІНЕРАЛЬНИХ ДОМІШОК 3
} ПІСЛЯЖНИВНИХ РЕШТОК КУКУРУДЗИ

\begin{abstract}
Анотація
У зв'язку з енергетичною кризою особливої уваги набуває виготовлення та застосування біопалива. Перспективним джерелом енергї для зерносушарок можуть стати післяжнивні рештки кукурудзи (ПРК). Виділяють наступні складові ПРК: стебло, листя, стрижень та обгортка качана. ПРК складають близько 55 ...60\% загальної маси рослини. Щорічний врожай зерна кукурудзи становить більше 20 мільйонів тонн. Теплотворна здатність при спалюванні пшеничної соломи складає 14,4 МДж/кг, ПРК-15,7 МДж/кг. Для порівняння теплотворна здатність деревини в середньому становить 14,24 МДж/кг, а природного газу 33,5 МДж/м³. Використання ПРК може значно скоротити потребу в імпортному газі.

Одним з напрямків використання рослинної сировини в якості палива є виготовлення гранул. Технологія передбачає очищення сировини від домішок, подрібнення та гранулювання. За схожою схемою виготовляють гранульовані комбікорми. Під час збирання врожаю комбайном, послідуючому транспортуванні та перевантажуванні, в зелену масу потрапляють різні засмічувачі у тому числі і мінеральні домішки у вигляді каменів. Потрапивши в дробарку камені призводять до пошкодження деталей здрібнюючого механізму, аварії і навіть вибуху. Очищення соломи від домішок в сільському господарстві здійснюють на пневмосепаруючих машинах. Але в технічній літературі відсутні данні щзо до відділення мінеральної домішки від ПРК. Проведені досліди з метою визначення можливості відділення мінеральних домішок від ПРК. Для визначення аеродинамічних характеристик сировину продували вертикальним повітряним струмом у лабораторному аналізаторікласифікаторі. Розміри представлених зразків ПРК в середньому становили близько $100 \ldots 150$ мм довжини. Також було представлено зразки мінеральних домішок у вигляді каменів розміром від 3 мм до 5 мм. Густина каменів складала $2000 \ldots 3000 \kappa 2 / \mathrm{M}^{3}$. Значення швидкості витання для різних анатомічних часток ПРК відрізняються між собою. Експериментальні дослідження з визначення швидкості витання різних частин ПРК показали, щзо найменша швидкість повітряного струму необхідна для листя (4,0...6,5 м/с), більша для стеблів $(7,5 \ldots 12,5$ м/с). Швидкість витання стрижнів знаходиться у діапазоні $10 \ldots 17$ м/с. Вологість зразків становила $11 \%$. Густина стрижнів складала 600 кг/м². При швидкості 17 м/с разом зі стержнями починають транспортуватися угору камені розміром приблизно до 3 мм у діаметрі.

В результаті проведених дослідів встановлено, щь листя та стебла можуть бути відділені повітряним потоком від крупних каменів, а відділення стрижнів від каменів ускладнено. Під дією повітряного потоку стрижні повертаються уздовж пневмосепаруючого каналу і розгортаються довгою віссю паралельно повітряному потоку, щчо призводить до зменшення площі міделевого перерізу та зменшення аеродинамічного опору. Тому для забезпечення потрібної сили, яка діє на стрижень з боку повітряного потоку, збільшують швидкість повітря, що обумовлює захоплення та сумісне переміщення каменів. Для удосконалення прочесу сепарування ПРК від каменів необхідно розробити живильний механізм сепаратора, 6 якому передбачити можливість орієнтації стрижнів у пневмосепаруючому каналі довгою віссю поперек повітряного потоку. Це дасть можливість зменшити потрібну для сепарування швидкість повітря та збільшити різницю у аеродинамічних силах, що діють на камені і стрижні. Відповідно, при иьому зменшиться енергоємність проиесу пневмосепарування та збільшиться ефективність відокремлення ПРК від каменів. Відділення дрібних каменів розміром менше за 3 мм тільки повітрям неможливо, оскільки вони підхоплюються повітряним потоком, щзо рухається зі швидкістю, необхідною для відділення стеблів $(7,5 \ldots 12,5 \mathrm{M} / \mathrm{c})$. Для відділення дрібних каменів запропоновано застосування решітних сепараторів з комбінованою продувкою повітрям. Для повного відділення мінеральної домішки від стрижснів кукурудзи рекомендовано застосовувати гідросепаратори.

Ключові слова: післяжнивні рештки кукурудзи, біопаливо, пневматичне сепарування, сепаруючи машини, паливо з
\end{abstract} рослинної сировини, очищення соломи від мінеральних домімок.

\section{ЛІТЕРАТУРА}

1. Кукурудзяне тепло: як можна додатково заробити на гектарі [Електроний ресурс]. - Режим доступу: // http. agravery.com/uk/posts/show/kukurudzane-teplo-ak-mozna-dodatkovo-zarobiti-na-gektari

2. Можливості заготівлі побічної продукиї̈ кукурудзи на зерно для енергетичного використання в Украӥні [Електроний ресурс]. - Режим доступy: // http://uabio.org/img/files/docs/position-paper-uabio-16-ua.pdf

3. Нелюбов А.И., Ветров Е.Ф. Пневмосепарирующие системы сельскохозяйственных машин. - М.: Машиностроение, 1977. $-192 \mathrm{c}$.

4. Технологическое оборудование предприятий по хранению и переработке зерна / А.Я. Соколов, В.Ф. Журавлев, В.Н. Душин и др.; Под ред. А.Я. Соколова. - 5-е изд., перераб. и доп. - М.: Колос, 1984. - 445с.

Надійшла 25.06.2018. До друку 03.08.2018. Рецензія 03.08.2018

Адреса для переписки: вул. Канатна, 112, м. Одеса, 65039 